\title{
ESTIMASI USIA BERDASARKAN ERUPSI GIGI MOLAR KETIGA PADA ETNIS TIONGHOA DI SURABAYA
}

\author{
Icha Artyas Annariswati ${ }^{1}$ Mieke Sylvia M.A.R ${ }^{2}$, Haryono Utomo ${ }^{2}$ \\ ${ }^{1,2}$ Universitas Airlangga; Jln. Airlangga 4 - 6. Surabaya 60286. Telp.: (031)5023715,5020170 \\ ${ }^{1}$ Jurusan S2 Ilmu Forensik, Sekolah Pascasarjana, UNAIR, Surabaya \\ ${ }^{2}$ Fakultas Kedokteran Gigi, UNAIR, Surabaya \\ e-mail: ${ }^{1}$ icha_syalala@icloud.com, miekesud@ymail.com, \\ haryonoutomo60@gmail.com
}

\begin{abstract}
Abstrak
Estimasi usia melalu gigi merupakan hal terpenting untuk identifikasi seseorang di kedokteran forensik dan bidang studi lainnya. Erupsi gigi adalah parameter dari perkembangan morfologi gigi yang dapat ditentukan dengan pemeriksaan klinis atau radiografi gigi. Tujuan penelitian ini adalah untuk mempelajari erupsi molar tiga pada populasi Tionghoa untuk kepentingan estimasi usia. Sebanyak 74 orthopantomogram yang terdiri dari 34 laki - laki dan 40 perempuan berusia antara 17 hingga 25 tahun telah dianalisa. Status erupsi molar ketiga dinilai menggunakan tahap perkembangan metode Demirjian yang dimodifikasi, dimana metode tersebut berdasarkan perkiraan tahapan mahkota dan akar gigi yang dilihat dari radiografi gigi. usia kronologis diperoleh dari tanggal lahir individu tersebut. perbedaan antara usia dental dan usia kronologis dianalisa menggunakan independent t-test. Hasil penelitian ini menunjukkan pada laki - laki nilai molar tiga kiri rahang bawah $p=0,170$ dan sisi kanan $p=0,163$, sedangkan pada perempuan nilai molar tiga kiri rahang bawah $p=0,560$ dan sisi kanan $p=$ 0,511 ( $p>0,05$ ), hal ini berarti tidak ada perbedaan signifikan antara usia dental dan usia kronologis. Kesimpulan dari penelitian ini metode Demirjian yang dimodifikaasi berdasarkan gigi molar tiga dapat digunakan pada populasi Tionghoa di Surabaya untuk estimasi usia.
\end{abstract}

Kata kunci: molar tiga, estimasi usia, metode Demirjian yang dimodifikasi, etnis Tionghoa, Surabaya

\begin{abstract}
Dental age estimation is of great importance for individual identification in forensic dentistry and many other fields of study. Tooth eruption is a parameter of developmental morphology that can be determined by clinical examinations as well as by dental X-rays. The aim of this study is to evaluate third molars eruption in Chinese population in Surabaya for age estimation. A total of 74 panoramic radiographs from 34 males and 40 females Chinese aged between 17 until 25 years were analyzed. The eruption status of the third molars were assessed using the developmental stages described by Demirjian's methode modified, which was based upon an assessment of crown and root formation stages from dental radiographs. Chronological age was obtained from the date of birth of adult. Difference between dental age and chronological age was analysed using independent t-test. The result of this study showed on males mandibular third molar left $p=0,170$ and right side $p=0,163$ in females mandibular third molar left $p=0,560$ and right side $p=0,511$ ( $p>0,05)$, it means no significant difference
\end{abstract}

JBP Vol. 17, No. 2, Agustus 2015-Icha Artays Annariswati 
Jurnal Biosains Pascasarjana Vol. 17 (2015) pp

(C) (2015) Program Pascasarjana Universitas Airlangga, Indonesia

between dental age and chonological age. The conclusion of this research was Demirjian's methode modified by third molar can be appliedt to Chinese population in Surabaya for age estimation.

Keywords: third molar, age estimation, Demirjian's methode modified, chinese population, Surabaya

\section{PENDAHULUAN}

Salah satu proses identifikasi adalah menentukan estimasi usia yang dapat dilakukan pada individu hidup maupun mati. Pada individu mati, estimasi usia merupakan bagian dari identifikasi korban mati pada kasus pembunuhan, aborsi janin, ataupun bencana massal (Panchbhai, 2011). Identifikasi usia selain merupakan hak asasi bagi korban, juga penting untuk berbagai keperluan legal, antara lain kasus pemalsuan usia ketenagakerjaan, pernikahan, pemalsuan usia atlet, perwalian anak dan keimigrasian dimana kasus tersebut banyak terjadi pada usia 17 tahun keatas (Alamsyah, 2005). Pembuktian hukum akan usia penting untuk menentukan apakah individu tersebut masih dalam kategori anak atau sudah dewasa, berkaitan dengan adanya perbedaan proses hukum atau peradilan pada anak dengan orang dewasa (Cameriere, 2007).

Bagian tubuh yang penting untuk identifikasi usia adalah gigi - geligi, karena gigi mempunyai daya tahan tinggi terhadap temperatur, kimiawi dan cuaca. Email gigi merupakan jaringan yang paling keras di tubuh manusia, paling tahan terhadap benturan maupun panas dan baru menjadi abu bila terkena panas lebih dari $450^{\circ} \mathrm{C}$ (Thevissen, 2009).

Estimasi usia melalui gigi pada usia muda dan anak - anak memerlukan ketelitian paling tinggi. Hal ini dikarenakan ada banyak gigi yang sedang mengalami perkembangan dan kalsifikasi secara bersamaan. Setelah usia remaja awal banyak gigi yang sudah terkalsifikasi dan erupsi kecuali untuk molar tiga. Hal ini membuat perkembangan molar tiga merupakan pilihan yang penting untuk estimasi usia pada masa remaja akhir ke awal usia duapuluhan (Thevissen, 2009).

Metode yang sering digunakan untuk menentukan usia dental adalah metode Demirjian (1973). Demirjian dalam penelitiannya mengklasifikasikan tahap perkembangan mahkota dan akar gigi pada semua gigi sampai molar dua. Kemudian metode ini dimodifikasi oleh beberapa peneliti dengan menggunakan gigi molar tiga sebagai indikator estimasi usia. Prinsip metode ini adalah berdasarkan tahap perkembangan gigi molar tiga mulai dari pembentukan mahkota sampai penutupan saluran akar.

Salah satu etnis yang lama tinggal di Indonesia adalah etnis Tionghoa. Bangsa Tiongkok adalah bangsa yang ekspansif, menyebar ke berbagai belahan dunia. Jumlah golongan Tionghoa di Indonesia diperkirakan 5\% dari penduduk Indonesia, berarti sedikitnya ada 12 juta golongan Tionghoa yang tersebar hampir di semua kota seluruh Indonesia. Di Surabaya, etnis Tionghoa berjumlah 7,5\% dari jumlah penduduk Surabaya dan merupakan etnis terbanyak tiga yang ada di Surabaya.

Berdasarkan latar belakang diatas, peneliti tertarik untuk melakukan penelitian mengenai bagaimana metode Demirjian yang dimodifikasi dalam memperkirakan usia 17 - 25 tahun pada etnis Tionghoa di Surabaya dan gigi molar tiga kanan atau kiri rahang bawah mana yang paling akurat dalam memperkirakan usia yang selanjutnya dapat memberikan manfaat dalam bidang kedokteran gigi forensik.

\section{TINJAUAN PUSTAKA}

\subsection{Morfologi dan Perkembangan Gigi Molar Tiga}

Molar tiga atau biasa disebut gigi bungsu adalah salah satu dari tiga gigi molar dalam gigi geligi manusia. Molar tiga pada manusia adalah gigi molar tetap yang erupsi terakhir kali di mulut. Gigi ini erupsi pada usia sekitar $17-25$ tahun.

Molar tiga rahang atas mempunyai bentuk yang bervariasi diantara semua gigi yang ada dalam mulut. Tipe utama dari molar tiga atas adalah apabila dilihat dari aspek oklusal terlihat seperti bentuk hati dan kemungkinan tidak adanya cusp distopalatal sehingga tidak memppunyai kontak distal. Carabelli cusp juga tidak ada pada molar tiga atas. Ukuran mahkota molar tiga atas cenderung kecil dan akar - akar molar tiga sering kali menyatu serta ukuran akar lebih kecil daripada akar molar pertama dan molar kedua (Beek, 2011). 
Molar tiga bawah mempunyai bentuk mahkota yang sangat mirip dengan molar kedua bawah, dengan 4 cuspis dan lebih banyak fisura tambahan yang berjalan dari fossa sentral. Bila dilihat dari permukaan oklusal, kecembungan permukaan bukal yang jelas mudah dibedakan dari permukaan lingual yang lebih datar. Bagian oklusal peripheral secara keseluruhan serupa dengan molar bawah lain yang secara kasar berbentuk bujur atau empat persegi, tetapi sudutnya cenderung lebih membulat sampai tingkat beberapa molar tiga bawah mempunyai bagan oklusal hampir bundar. Lengkungan akar molar tiga bawah selalu ke distal, dan biasanya lebih besar daripada molar kedua bawah. (Harshanur, 2011). Tahapan pertumbuhan gigi molar tiga terdiri dari :

- Tahap inisiasi yang terjadi pada umur 3.5 -4 tahun.

- Kalsifikasi dimulai pada umur $8-10$ tahun

- Pembentukan mahkota, pada umur 12 16 tahun.

- Tahap erupsi, pada umur 17 - 21 tahun. . ( Mcdonald dan Avery, 2011).

\subsection{Metode Demirjian yang Dimodifikasi}

Metode Demirjian mengklasifikasikan tahap perkembangan mahkota dan akar gigi mulai gigi insisivus satu sampai ke molar dua. Beberapa peneliti kemudian memodifikasi metode Demirjian dengan menggunakan gigi molar tiga sebagai indikator, salah satu peneliti yang memodifikasi adalah Olze (2003) yang menggunakan gigi molar tiga membagi pertumbuhan mahkota dan akar gigi molar tiga menjadi delapan tahap kalsifikasi dari A $-\mathrm{H}$, yaitu:

(A) awal kalsifikasi gigi geligi, fusi belum terbentuk.

(B) kalsifikasi titik-titik oklusal disertai fusi dari kalsifikasi pada bagian lain.

(C) mahkota sudah terbentuk setengah.

(D) pembentukan mahkota selesai sampai cemento-enamel junction. Garis superior ruang pulpa pada gigi uniradikuler mempunyai bentuk melekuk, konkaf terhadap regio servikal. Proyeksi tanduk pulpa dapat dilihat, memberikan garis besar berbentuk seperti ujung payung.

(E) panjang akar gigi lebih pendek daripada tinggi mahkota.

(F) panjang akar gigi sama atau melebihi tinggi mahkota.
(G) pembentukan akar telah selesai tetapi foramen apikal masih terbuka.

$(\mathrm{H})$ foramen apikal telah tertutup dan membran periodontal mempunyai lebar yang seragam di sekitar akar dan apeks.

Metode Demirjian yang dimodifikasi sering digunakan karena metode ini memiliki hasil pengukuran estimasi usia lebih baik dengan standar deviasi yang kecil, selain itu lebih akuratdan lebih sederhana karena hanya berdasarkan observasi tahap perkembangan dan pertumbuhan mahkota dan akar gigi molar tiga, tanpa melakukan pengukuran sehingga kesalahan akibat distorsi foto radiografik dapat dihindari. Hasil observasi estimasi usia tidak dipengaruhi oleh berbagai bentuk variasi gigi molar tiga seperti posisi erupsi gigi molar tiga, gigi impaksi serta distorsi foto radiografik dikarenakan metode ini mengamati tiap tahap kalsifikasi gigi molar tiga. Faktor tersebut menjadi kelebihan menggunakan metode ini dalam estimasi usia. 


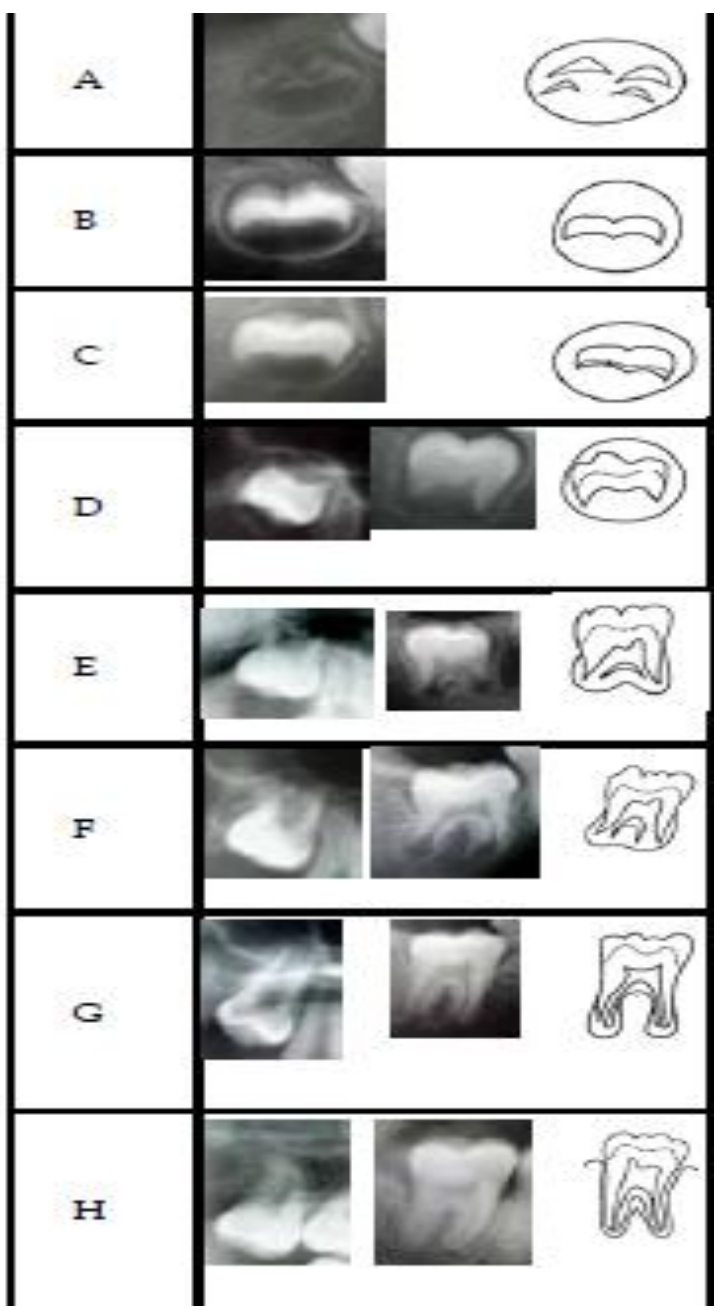

Gambar 1 : Delapan tahapan metode Demirjian 'yang dimodifikasi pada gigi molar tiga

\subsection{Etnis Tionghoa di Surabaya}

Istilah etnis Tionghoa mengacu pada sebuah kelompok orang dengan elemen budaya yang dikenali sebagai atau dapat disebabkan oleh budaya Tionghoa. Etnis Tionghoa pada dasarnya dapat dikategorikan ke dalam dua kelompok besar, yaitu mereka yang disebut dengan peranakan dan totok (Suryadinata, 2014).

Bangsa Tiongkok adalah bangsa yang ekspansif, menyebar ke berbagai belahan dunia.. Salah satu tujuan persebaran etnis Tionghoa adalah Indonesia lebih tepatnya di Surabaya. Selain jalur darat, jalur laut dipilih karena dirasa lebih efektif dan menjangkau hingga ke pelosok Indonesia. Kala itu etnis Tionghoa tertuju pada kota Surabaya yang memang terletak di pesisiran pantai utara Jawa.
Kebijakan wijkenstelsel dan passenstelsel pada zaman kolonial yang melokalisasi pemukiman etnis Tionghoa merupakan titik awal tumbuhnya ekslusivisme di kalangan etnis Tionghoa. Kebijakan wijkenstelsel adalah sistem kampung Tionghoa yang dibuat oleh kolonial Belanda guna membatasi ruang gerak etnis Tionghoa untuk menghindari sentimen anti Tionghoa kala itu. Sedangkan kebijakan passenstesel adalah kebijakan Belanda untuk diadakannya surat jalan khusus bagi etnis Tionghoa. Belanda menetapkan orang-orang Timur Asing yaitu orang Melayu, Arab, India, dan Tionghoa pada lapisan kedua dalam sistem pelapisan masyarakat. Di bawah orang - orang Belanda dan Eropa lain dan di atas lapisan terendah yaitu orang - orang pribumi. Sehingga berpengaruh juga terhadap sistem pemerintahan kota. (Suryadinata, 2014).

Suku Jawa adalah suku mayoritas di Surabaya. Meskipun Jawa adalah suku mayoritas $(83,68 \%)$, tetapi Surabaya juga menjadi tempat tinggal berbagai suku bangsa di Indonesia, termasuk suku Madura (7,6\%), Tionghoa (7,5\%), Arab (2,04\%), dan sisanya merupakan suku bangsa lain atau warga asing. Etnis Tionghoa merupakan etnis terbesar ketiga di Surabaya, yang banyak tinggal di kampung peTionghoan (Tionghoa peranakan) daerah Surabaya barat.

\section{METODE PENELITIAN}

Jenis penelitian yang digunakan adalah penelitian analitik observasional dengan sampel sebanyak 74 sampel yang terdiri dari 34 sampel laki - laki dan 40 sampel perempuan. Sampel berasal dari foto radiogram panoramik pasien Etnis Tionghoa dari klinik Dr. Daniel's Aesthetic Center yang berusia $17-25$ tahun, merupakan keturunan etnis Tionghoa hingga 3 generasi di atasnya, Gigi molar tiga rahang bawah kanan dan kiri ada, tidak mempunyai kelainan pertumbuhan, endokrin, dan gangguan nutrisi yang dapat mempengaruhi pertumbuhan, serta foto panoramik harus jelas terbaca.

\section{HASIL DAN PEMBAHASAN}

Berdasarkan dari penelitian pada 74 sampel menunjukkan hasil $p$ sebesar 0,170 untuk sampel laki - laki dan $p$ sebesar 0,560 untuk sampel perempuan, hal ini menunjukkan tidak ada perbedaan signifikan antara usia kronologis dan usia dental gigi molar tiga kiri bawah. Sedangkan, untuk hasil uji statistik antara usia kronologis dan 
Jurnal Biosains Pascasarjana Vol. 17 (2015) pp

(C) (2015) Program Pascasarjana Universitas Airlangga, Indonesia

usia dental gigi molar tiga kanan bawah akurat karena selisih rata - ratanya lebih sedikit menunjukkan tidak ada perbedaan signifikan

dengan usia kronologis baik pada sampel laki - laki

\begin{tabular}{|c|lcc|}
\hline $\begin{array}{c}\text { Jenis } \\
\text { kelamin }\end{array}$ & Pengamatan & Mean & Standar deviasi \\
\hline Laki - laki & Usia Kronologis & 21.8950 & 2.27029 \\
& Usia dental gigi molar tiga kiri bawah & 20.6765 & 2.22614 \\
& Usia dental gigi molar tiga kanan bawah & 20.6206 & 4.06379 \\
\hline Perempuan & Usia Kronologis & 20.1608 & 1.83780 \\
& Usia dental gigi molar tiga kiri bawah & 19.9475 & 2.44760 \\
& Usia dental gigi molar tiga kanan bawah & 20.2575 & 2.20871 \\
& & & \\
\hline Laki - laki & Usia Kronologis & 20.9576 & 2.21170 \\
+ & Usia dental gigi molar tiga kiri bawah & 20.2824 & 2.28187 \\
Perempuan & Usia dental gigi molar tiga kanan bawah & 20.6500 & 2.12811 \\
\hline
\end{tabular}

dengan $p$ sebesar untuk sampel laki - laki dan $p$ maupun perempuan pada populasi etnis Tionghoa. sebesar 0,051 untuk sampel perempuan 0,198. Hal ini menunjukkan bahwa metode Demirjian yang dimodifikasi dapat diaplikasikan pada etnis Tionghoa. Hal tersebut sesuai dengan penelitian Guo Li (2011) bahwa metode Demirjian yang dimodifikasi dapat digunakan untuk estimasi usia pada populasi dewasa muda di Tiongkok Barat dengan melihat perkembangan gigi molar tiga. Metode ini juga dapat diaplikasi pada populasi Tiongkok Utara yang berusia $14-26$ tahun dimana tidak ada perbedaan signifikan antara usia kronologis dan usia dental menggunakan gigi molar tiga (Yu-cheng Guo, 2013).

Bila dilihat dari rata - rata selisih usia kronologis dengan usia dental molar tiga kiri bawah pada laki - laki 2,34 tahun dan perempuan 1,16 tahun. Sedangkan, rata - rata selisih usia kronologis dengan usia dental molar tiga kanan bawah pada laki - laki 2,69 tahun dan perempuan 1,30 tahun. Dari hasil tersebut dapat diketahui bahwa usia dental molar tiga kiri bawah lebih Dong Lin Zeng (2010) meneliti perkembangan gigi molar tiga rahang atas dan rahang bawah terhadap 3100 foto panoramik populasi dewasa muda Han di Tiongkok selatan, dari penelitan tersebut menyatakan bahwa gigi molar tiga rahang bawah kiri bawah lebih akurat. Hal tersebut dapat dikarenakan tahap - tahap kalsifikasi dan pembentukan akar gigi molar tiga kiri bawah lebih cepat dua bulan daripada molar ketiga kanan bawah, sehingga waktu erupsinya lebih cepat dan dapat digunakan untuk mengunyah.

Jenis kelamin adalah salah satu faktor yang mempengaruhi waktu dan urutan erupsi. Hasil penelitian ini berdasarkan jenis kelamin terlihat adanya perbedaan rata - rata pada masing - masing kelompok. Rata - rata usia kronologis pada sampel laki - laki sebesar 21,89 tahun, sedangkan rata rata usia kronologis pada sampel perempuan yaitu sebesar 20,16 tahun dengan selisih 1,72 tahun. Dari hasil uji komparasi independent $t$-test terdapat

Tabel 1. Mean dan standar deviasi

Tabel 2. Uji komparasi usia kronologis dan usia dental antara masing - masing kelompok

\begin{tabular}{|c|l|c|}
\hline $\begin{array}{c}\text { Jenis } \\
\text { Kelamin }\end{array}$ & \multicolumn{1}{|c|}{ Pengamatan } & Nilai signifikasi \\
\hline \multirow{3}{*}{ Laki -laki } & Usia kronologis dengan usia dental gigi molar tiga kiri bawah & 0,170 \\
& Usia kronologis dengan usia dental molar tiga kanan bawah & 0,163 \\
\hline Perempuan & Usia kronologis dengan usia dental gigi molar tiga kiri bawah & 0,560 \\
& Usia kronologis dengan usia dental gigi molar tiga kanan bawah & 0,511 \\
\hline $\begin{array}{c}\text { Laki - laki }+ \\
\text { Perempuan }\end{array}$ & Usia kronologis dengan usia dental gigi molar tiga kiri bawah & 0.051 \\
\hline
\end{tabular}


perbedaan yang bermakna antara usia kronologis sampel laki - laki dan perempuan dimana $p<0,05$ yaitu sebesar 0,024 .

Sampel pada penelitian ini berusia antara 17 - 25 tahun yang menurut Huebner (2009) usia tersebut dikategorikan dalam kriteria masa remaja akhir atau late adolescent dimana pada perempuan berusia $18-21$ tahun dan pada laki-laki $19-21$ tahun. Menurut Soetjiningsih (2004) masa remaja merupakan masa peralihan antara masa anak anak yang dimulai saat terjadinya kematangan seksual yaitu antara usia 11 atau 12 tahun sampai dengan 20 tahun, yaitu masa menjelang dewasa muda Pada masa ini pertumbuhan fisik merupakan pertumbuhan yang paling pesat. Pertumbuhan fisikdalah perubahan fisik secara kuantitatif yang menyangkut peningkatan ukuran dan struktur biologis. Pertumbuhan ini meliputi perubahan ukuran tubuh, perubahan proporsi tubuh, perubahan pada ciri - ciri kelamin primer dimana alat kelamin mulai berfungsi dan perubahan ciri ciri kelamin sekunder dimana ciri - ciri inilah yang membedakan bentuk fisik laki - laki dengan perempuan. Papalia \& Olds (2010) menjelaskan bahwa pada masa remaja akhir pertumbuhan fisik perempuan sudah sempurna dan matang, sedangkan pada laki - laki masih terus berlanjut khususnya pada peningkatan berat badan, tinggi badan, massa otot dan pertumbuhan rambut.

Usia dental gigi molar tiga kiri bawah pada sampel laki - laki mempunyai rata - rata sebesar 20.67, sedangkan rata - rata sampel perempuan yaitu sebesar 19.94 dengan selisih 0,73 tahun, dari hasil uji komparasi tidak ada perbedaan bermakna antara usia dental gigi molar tiga kiri bawah laki laki dan perempuan yaitu dengan nilai $\mathrm{p}$ sebesar 0,904 . Sedangkan, usia dental gigi molar tiga kanan bawah pada sampel laki - laki mempunyai rata rata sebesar 20,62 tahun dan untuk rata - rata sampel perempuan yaitu sebesar 20,25 tahun dengan selisih hanya 0,37 tahun dan dari hasil uji komparasi tidak ada perbedaan bermakna pula dengan $\mathrm{p}$ sebesar 0,568. Hal ini berarti usia dental berdasarkan metode Demirjian yang dimodifikasi dapat dipakai pada sampel laki - laki maupun perempuan namun untuk keperluan identifikasi

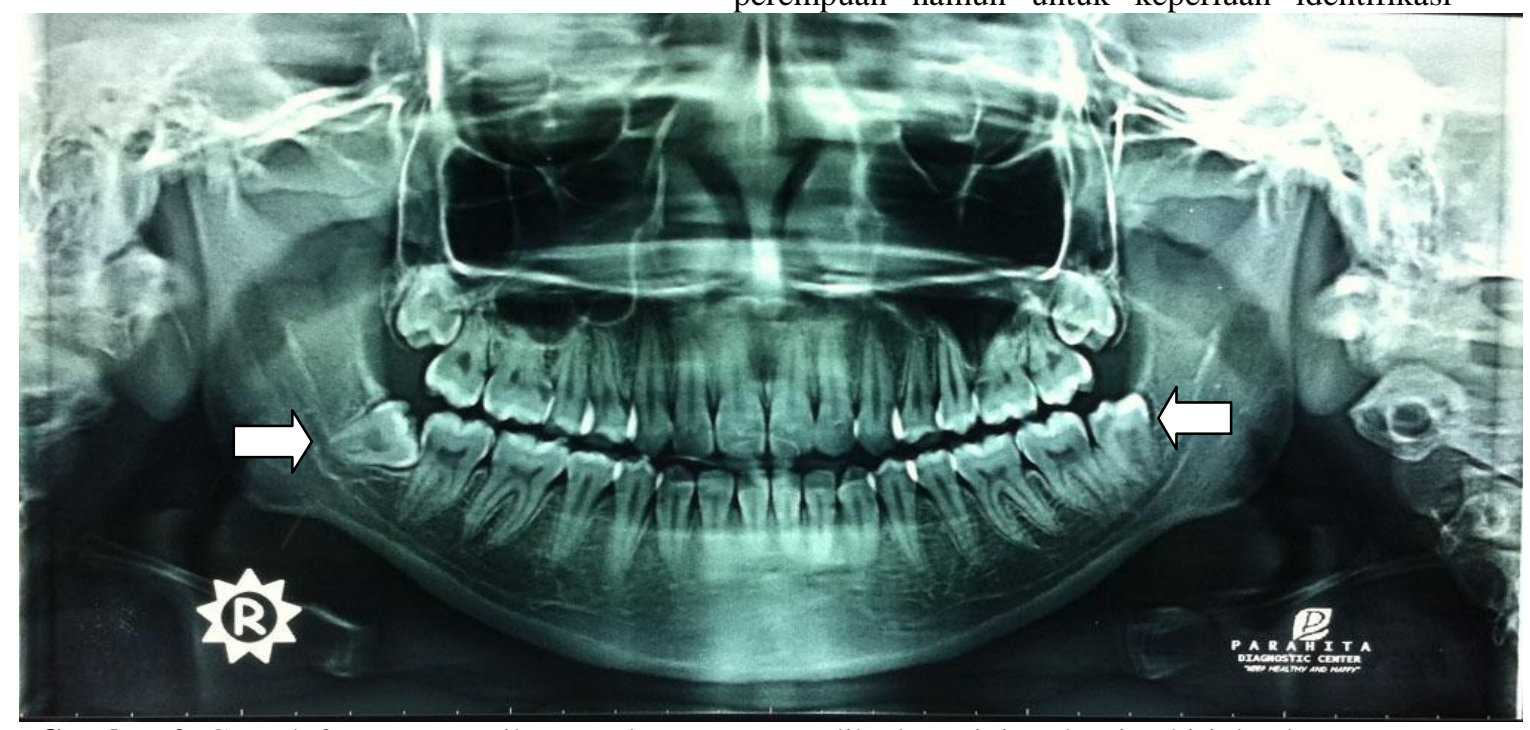

Gambar 2. Contoh foto panoramik sampel yang memperlihatkan gigi molar tiga kiri dan kanan

jenis kelamin berarti tidak dapat hanya melihat foto panoramik gigi. Proses erupsi geligi manusia hanya berlangsung antara usia 6 bulan hingga 17 tahun, sehingga untuk memperkirakan usia di atas 17 tahun tidak semudah prakiraan usia di bawah 17 tahun. Setelah usia 17 tahun banyak gigi yang sudah terkalsifikasi dan erupsi kecuali untuk molar tiga. Selain itu, penggunaan indikator biologis lainnya seperti penyatuan epifisis, perubahan simfisis pubis, tulang pergelangan dan penyatuan sutura tengkorak tidak begitu akurat pada masa masa ini. Hal ini membuat perkembangan molar tiga merupakan pilihan yang penting untuk estimasi usia pada masa remaja akhir ke awal usia duapuluhan (Thevissen, 2009). 
Salah satu keterbatasan metode estimasi usia dengan menggunakan gigi molar tiga adalah tingginya frekuensi variasi posisi, erupsi, dan morfologi gigi molar tiga Masalah lain yang perlu dipertimbangkan adalah tingginya frekuensi kehilangan gigi molar tiga disebabkan karena pencabutan gigi ataupun karena tidak ada benih gigi molar tiga ini.

\section{KESIMPULAN DAN SARAN}

Berdasarkan penelitian estimasi usia berdasarkan gigi molar tiga pada etnis Tionghoa yang berusia $17-25$ tahun dapat diambil kesimpulan sebagai berikut :

1. Estimasi usia berdasarkan molar tiga menggunakan metode Demirjian yang dimodifikasi dapat diaplikasikan pada populasi etnis Tionghoa.

2. Tidak ada perbedaan antara laki - laki dan perempuan berdasarkan usia dental.

3. Selisih rata - rata usia dental gigi molar tiga kiri bawah dengan usia kronologis lebih sedikit daripada gigi molar tiga kanan bawah.

Adapun saran untuk penelitian selanjutnya diharapkan adanya penelitian untuk membandingkan gigi molar tiga atas dan bawah serta diperlukan penelitian untuk populasi yang berbeda dengan jumlah sampel yang lebih banyak.

\section{DAFTAR PUSTAKA}

Alamsyah R, Situmarong N. 2005. Dampak Gigi Molar Tiga Mandibula Impaksi Terhadap Kualitas Hidup Mahasiswa Universitas Sumatera Barat. Dentika Dental Journal 10(2): pp.473-475.Maofeng Q., 2013. "The Chronological Age Estimation of Third Molar Mineralization of Han Population In Southwestern China". J Forensic Science Vol. 98 , No. 462, pp. 352-365

Cameriere R, Ferrante L, Belcastro M, 2007. "Age Estimation by Pulp/Tooth Ratio In Canines by Periapical X-Rays". J Forensic Sci Vol 52,pp.166-170.

Guo Li. 2011. "Dental Age Estimation from the Developmental Stage of the Third Molars in Western Chinese Population". Forensic Science International Vol. 219, pp.158-164.

Harshanur IW. 2011. Anatomi Gigi, EGC, Jakarta. Huebner A. Adolescent Growth and Development
Transition. $\quad$ Retrieved from http://www.ext.vt.edu/ pubs/family/350-380. On 10 Oct 2015.

Olze A, Pynn B, Kraul V, Schulz R, Heinecke A, Pfeiffer H, Schmeling A, 2011. "Dental Age Estimation Based on Third Molar Eruption In First Nations People Of Canada". J Forensic Odontostomatol Vol.1: 32-8.

Panchbhai AS., 2011. "Dental radiographic indicators, a key to age estimation. Dentomaxillofacial Radiology"; Journal of Health And Research Vol. 4, pp.199-212.

Shakuntala, Roopak B, Devi RS, Mathew S. 2011.“Reliability of Dental Age (Demirjian's method) and Chronological Age Estimation of Rural Children of South Bangalore". Journal of Health And Research Vol. 2, pp.10 - 12.

Soetjiningsih. 2004. Tumbuh Kembang Remaja dan Permasalahannya. Sagung Seto.Jakarta.

Suryadinata, 2014. Dilema Minoritas Tionghoa. Grafitipers, Jakarta.

Thevissen PW, Pittayapat P, Fieuws S, Willems G, 2009. "Estimating age of majority on third molars developmental stages in young adults from Thailand using a modified scoring technique". J Forensic Science Vol. 54, pp.428-432.

Yu-cheng G. 2013. "Studies of the chronological course of third molars eruption in a northern Chinese population". Oral Biology Archive Vol.2,pp.906-911. 